\title{
DETERMINAN KECURANGAN AKUNTANSI DI LINGKUNGAN PERGURUAN TINGGI
}

\author{
Johan Arifin \\ johan.arifin@uii.ac.id \\ Mega Laksmitha Pertiwi \\ Universitas Islam Indonesia Yogyakarta
}

\begin{abstract}
Fraud can be occured in various institutions, both in business or public sector institutions. In recent years, many cases such as corruption, embezzlement of funds, and budget mark-ups have been found in various educational institutions especially universities in Indonesia. This study aims to examine whether some potential variables as predictors of accounting fraud such as individual morality, internal control systems, and asymmetric information affect accounting fraud in educational institutions. The population of this research are all universities in Daerah Istimewa Yogyakarta (DIY), a city which known as a 'student city' that be a benchmark of the quality of education in Indonesia. This study uses 86 respondents who are staff of finance from seven well-known universities in DIY. The results of the regression analysis showed that individual morality and internal control systems had a significant negative effect on accounting fraud, while asymmetric information had no significant effect on accounting fraud. This research is expected to provide input to the management of educational institutions especially universities in solving the problem of accounting fraud, so they can provide the best service to the community.
\end{abstract}

Key words: morality; internal control; asymmetry of information; accounting fraud.

\section{ABSTRAK}

Kecurangan bisa terjadi pada berbagai institusi, baik pada institusi bisnis maupun sektor publik. Pada beberapa tahun terakhir ini, berbagai kasus seperti korupsi, penggelapan dana, dan mark-up anggaran telah ditemukan pada berbagai institusi pendidikan terutama perguruan tinggi di Indonesia. Studi ini bertujuan untuk menguji apakah variabel-variabel potensial sebagai prediktor kecurangan akuntansi seperti moralitas individu, sistem pengendalian internal, dan informasi asimetri berpengaruh terhadap kecurangan akuntansi pada institusi pendidikan. Populasi penelitian ini adalah semua perguruan tinggi yang terdapat di wilayah Daerah Istimewa Yogyakarta (DIY), yang merupakan sebuah kota dengan julukan 'kota pelajar' yang menjadi tolok ukur kualitas pendidikan di Indonesia. Studi ini menggunakan 86 responden yang merupakan staf bagian keuangan dari 7 perguruan tinggi ternama di DIY. Hasil analisis regresi menunjukkan bahwa moralitas individu dan sistem pengendalian internal berpengaruh negatif signifikan terhadap kecurangan akuntansi, sedangkan informasi asimetri tidak berpengaruh signifikan terhadap kecurangan akuntansi. Penelitian ini diharapkan dapat memberikan masukan kepada pengelola institusi pendidikan khususnya perguruan tinggi dalam memecahkan permasalahan kecurangan akuntansi, sehingga mereka dapat memberikan pelayanan terbaik kepada masyarakat.

Kata kunci: moralitas; pengendalian internal; informasi asimetri; kecurangan akuntansi.

\section{PENDAHULUAN}

Organisasi sektor publik merupakan organisasi yang menyediakan pelayanan bagi masyarakat. Dalam praktiknya, organisasi sektor publik dapat berupa institusi pemerintahan, partai politik, rumah sakit, dan berbagai institusi pendidikan, termasuk perguruan tinggi (Vries et al., 2015). Selama ini, organisasi sektor publik, tidak pernah lepas dari isu kecurangan (fraud), padahal organisasi sektor publik memiliki tanggung jawab langsung kepada masyarakat, karena sejatinya tujuan organisasi sektor publik adalah memberikan pelayanan kepada 
masyarakat (public services). Perguruan Tinggi Negeri (PTN) sebagai lembaga sektor publik tidak terlepas dari tindak kecurangan akuntansi. Badan Pemeriksa Keuangan (BPK) pada tahun 2010 melakukan pemeriksaan terhadap perguruan tinggi negeri di Indonesia. Dari pemeriksaan tersebut diperoleh hasil bahwa terdapat beberapa tindakan kecurangan pada beberapa perguruan tinggi yang diperiksa, diantaranya adalah terdapat sisa dana bantuan sosial yang tidak disalurkan sebagai mana mestinya dan tidak disetorkan ke kas negara. Selain itu, terdapat pembayaran ganda honorarium dan perjalanan dinas, serta adanya rekening fiktif yang dibuka tanpa sepengetahuan kementerian keuangan sehingga mengakibatkan rekening tersebut bersifat ilegal (Thoyibatun, 2012).

Kasus korupsi yang melanda perguruan tinggi tidak hanya masalah penggelapan dana dan mark up anggaran, namun pengelolaan aset perguruan tinggi negeri juga rawan menjadi sasaran tindak kecurangan (Temaluru et al., 2016). Pusat Kajian Anti Korupsi Universitas Gadjah Mada (PukatUGM) menyatakan bahwa dari data trend corruption report (TCR) Pukat, selama bulan Januari hingga Juni 2014 terdapat 10 orang tersangka korupsi dari sektor pendidikan. Modus korupsi ini didominasi pada sektor pengadaan barang dan jasa serta pengelolaan aset universitas (Kabar Korupsi, 2014). Dari penelitian yang dilakukan di beberapa negara lain juga diperoleh kesimpulan bahwa sektor pengadaan barang dan jasa mendominasi kasus korupsi pada lembaga sektor publik termasuk perguruan tinggi (Sargiacomo et al., 2015) dan (Auriol et al., 2016).

Sehubungan dengan hal tersebut, berbagai penelitian mengenai kecurangan akuntansi telah banyak dilakukan sebagai upaya untuk mempelajari faktor-faktor yang menyebabkan terjadinya kecurangan yang dilakukan oleh oknum instansi tertentu. Aranta (2013) dan Eliza (2015) mengungkapkan bahwa variabel moralitas aparat berpengaruh negatif terhadap ke- curangan akuntansi, sedangkan variabel asimetri informasi berpengaruh positif terhadap kecurangan akuntansi. Selanjutnya Aryanto et al. (2013) dalam penelitiannya mengungkapkan bahwa sistem pengendalian internal, sistem kompensasi dan asimetri informasi tidak berpengaruh terhadap kecurangan akuntansi. Terkait dengan tindak kecurangan tersebut, lebih lanjut Kerler dan Killough (2009) menyatakan bahwa semakin tinggi level penalaran moral individu akan semakin cenderung tidak berbuat kecurangan akuntansi. Selain faktor moralitas individu yang merupakan faktor internal setiap pegawai yang terlibat dalam institusi, terdapat sistem pengendalian internal yang sejatinya dirancang sebagai upaya penanggulangan berbagai kecurangan (Joseph et al., 2015). Selanjutnya Prawira et al. (2014) menjelaskan bahwa pengendalian internal merupakan suatu proses yang dijalankan oleh dewan komisaris, manajemen, dan personel lainnya pada sebuah entitas yang didesain untuk memberikan keyakinan memadai tentang pencapaian tiga golongan tujuan berikut: (1) Keandalan laporan keuangan, (2) Efektifitas dan efisiensi operasi, serta (3) Kepatuhan terhadap hukum dan peraturan yang berlaku. Selain faktor moral dan pengendalian internal, Najahningrum (2013) menjelaskan bahwa informasi asimetri merupakan keadaan dimana pihak dalam perusahaan mengetahui informasi yang lebih baik dibanding pihak luar perusahaan (stakeholder). Jika terjadi kesenjangan informasi antara pihak pengguna dan pihak pengelola, maka akan membuka peluang bagi pihak pengelola dana untuk melakukan kecurangan.

Isu tentang kasus kecurangan akuntansi pada lembaga sektor publik telah melanda institusi pendidikan di Indonesia. Salah satunya adalah pada akhir tahun 2012, Indonesia digemparkan oleh kasus korupsi di sektor perguruan tinggi negeri, yang berdasarkan hasil audit BPK RI, negara mengalami kerugian mencapai Rp. 309,7 miliar atas kecurangan yang dilakukan (Aryanto et al., 2013). Penelitian yang terkait 
dengan masalah korupsi di lingkungan perguruan tinggi sangat menarik dilakukan karena para pelaku merupakan pihak yang mempunyai latar belakang pendidikan yang cukup baik, bahkan sangat mengetahui dampak dari kegiatan korupsi bagi masyarakat.

\section{TINJAUAN TEORETIS}

\section{Kecurangan Akuntansi}

Kecurangan akuntasi merupakan suatu tindakan yang ilegal. Menurut Agrawal dan Cooper (2015) kecurangan merupakan konsep legal yang luas, menggambarkan setiap upaya penipuan yang disengaja, yang dimaksudkan untuk mengambil aset atau hak orang atau pihak lain. Sedangkan Kassem dan Higson (2016) menjelaskan bahwa kecurangan akuntansi dikelompokkan menjadi tiga, meliputi kecurangan dalam laporan keuangan, penyalahgunaan aset, dan korupsi.

Kecurangan dalam laporan keuangan merupakan suatu perbuatan memanipulasi laporan keuangan untuk kepentingan tertentu. Tindakan ini dilakukan oleh pejabat atau eksekutif suatu perusahaan atau instansi pemerintahan untuk menyembunyikan kondisi keuangan yang sebenarnya melalui rekayasa keuangan dalam penyajian laporan keuangan, hal ini dilakukan untuk mendapatkan keuntungan. Penyalahgunaan aset merupakan bentuk kecurangan yang paling mudah terdeteksi karena sifatnya dapat diukur atau dihitung (Johnson et al., 2014). Dalam istilah hukum, mengambil aset secara ilegal yang dilakukan oleh seseorang yang menerima wewenang untuk mengelola aset tersebut disebut penggelapan. Sedangkan korupsi merupakan suatu penyelewengan atau penyalahgunaan uang negara maupun perusahaan untuk kepentingan pribadi atau orang lain (Barr dan Serra, 2010). Jenis kecurangan dalam bentuk korupsi ini merupakan kecurangan yang paling banyak terjadi di negara-negara berkembang yang penegakan hukumnya lemah. Berbagai isu terkait dengan kecurangan akuntansi menuai berbagai perhatian terutama para peneliti yang berusaha mengungkapkan bagaimana dan mengapa kecurangan akuntansi dapat terjadi. Puspasari dan Suwardi (2012) dalam penelitiannya menggunakan metode eksperimen faktorial $2 \times 2$ untuk menguji faktorfaktor yang mempengaruhi kecurangan akuntansi, dimana hasilnya mengungkapkan bahwa terdapat interaksi antara level moral individu dan pengendalian internal terhadap kecurangan akuntansi. Sedangkan Prawira et al. (2014) dalam penelitian yang dilakukannya di berbagai BUMD di kabupaten Buleleng mengungkapkan bahwa moralitas individu, asimetri informasi dan efektifitas pengendalian internal berpengaruh negatif terhadap kecurangan akuntansi. Lebih lanjut Eliza (2015) dalam penelitiannya mengenai kecurangan akuntansi pada berbagai dinas di pemerintah daerah kota Padang Sumatera Barat mengungkapkan bahwa moralitas individu dan sistem pengendalian internal perusahaan berpengaruh negatif terhadap tingkat kecurangan akuntansi. Beberapa hasil penelitian tersebut mengindikasikan bahwa moralitas dan pengendalian internal merupakan faktor dominan yang mempengaruhi kecurangan akuntansi pada suatu organisasi. Namun demikian, dari salah satu penelitian terdahulu diperoleh informasi bahwa faktor asimetri informasi juga dapat dijadikan prediktor terhadap terjadinya kecurangan akuntansi.

\section{Moralitas Individu}

Aranta (2013) menyatakan bahwa kriteria mutu moral seseorang adalah hal kesetiaannya pada hatinya sendiri. Moralitas individu terhadap suatu tindakan memiliki pengertian apakah moral suatu tindakan tersebut baik atau buruk. Menurut Zhang dan Zhao (2017) salah satu teori perkembangan moral yang banyak digunakan dalam penelitian etika adalah model Kohlberg. Model tersebut terdiri melalui tiga tahapan, yaitu: (1) tahapan pre-conventional, (2) tahapan conventional, dan (3) tahapan postconventional. 
Tahap pre-conventional merupakan tahapan yang paling rendah, pada tahapan ini individu melakukan suatu perbuatan atau tindakan didasari oleh rasa takut terhadap hukum yang berlaku di lingkungan sekitarnya. Terlepas dari hukum yang berlaku, individu pada tahapan ini melakukan suatu tindakan atas dasar kepentingan pribadi. Tahap selanjutnya adalah conventional, pada tahap ini interaksi individu dengan orang-orang di sekitarnya memberikan pengaruh dalam melakukan suatu tindakan atau perbuatan. Suatu tindakan yang dilakukan oleh individu merupakan hasil persetujuan orang-orang di sekitarnya seperti teman atau keluarga dan juga peraturan yang berlaku di masyarakat. Pada tahap post-conventional, individu sudah tidak mementingkan kepentingan pribadinya dalam melakukan suatu perbuatan melainkan atas dasar kepentingan orang lain dan sesuai dengan hukum-hukum universal yang cakupannya lebih luas dibanding hukum atau aturan yang berlaku di masyarakat atau tempatnya bekerja.

\section{Sistem Pengendalian Internal (SPI)}

Pada dasarnya, sebuah organisasi didirikan dengan sebuah tujuan dan cita-cita yang hendak dicapai, namun pada kenyataannya proses untuk mencapai tujuan organisasi tidaklah mudah. Dalam proses tersebut adakalanya terdapat banyak kendala yang dihadapi oleh suatu organisasi, baik yang berasal dari pihak internal maupun eksternal. Jusup (2010) menyatakan bahwa sistem pengendalian internal merupakan sebuah proses yang dipengaruhi oleh banyak pihak, meliputi dewan komisaris, manajemen, serta personil satuan usaha lainnya yang dirancang untuk memperoleh keyakinan memadai tentang pencapaian tujuan dalam hal: (1) keandalan laporan keuangan, (2) kesesuaian dengan peraturan yang berlaku, dan (3) efektivitas dan efisiensi operasi.

Salah satu kendala internal yang timbul dalam sebuah organisasi adalah kecurangan (fraud) yang dilakukan oleh pegawai atau staf dalam organisasi (Maulidi, 2016). Dengan SPI yang baik diharapkan organisasi dapat menanggulangi permasalahannya atau lebih baik jika dapat mendeteksi dan mencegah masalah tersebut sedini mungkin. Jusup (2010) menyebutkan bahwa Committee of Sponsoring Organizations (COSO) mengenalkan lima komponen struktur pengendalian intern yang saling berkaitan, meliputi: (1) Lingkungan Pengendalian, (2) Penilaian Risiko, (3) Aktivitas Pengendalian, (4) Informasi dan Komunikasi, dan (5) Pemantauan. Dalam penelitian ini, indikator yang digunakan untuk mengukur SPI didapatkan dari komponen pengendalian intern yang dirumuskan oleh Committee of Sponsoring Organizations (COSO) tersebut.

\section{Informasi Asimetri}

Informasi Asimetri timbul karena manajer sebagai agen mengetahui informasi lebih banyak dibanding prinsipal mengenai kondisi internal perusahaan dan keberlangsungan perusahaan dimasa yang akan datang (Breeden dan Viswanathan, 2016). Teori keagenan yang berkembang sejak tahun 1970-an memungkinkan terjadinya asimetri karena dalam praktiknya, manajer memiliki peran secara aktif dalam kegiatan operasional perusahaan sehingga informasi internal perusahaan dapat dengan mudah diperoleh. Ketika informasi tersebut disampaikan tidak sesuai dengan keadaan yang sebenarnya kepada prinsipal, umumnya demi kepentingan manajemen, disitulah terjadi asimetri informasi (Roberts, 2015).

Suatu organisasi sektor publik memiliki demensi akuntabilitas publik yang meliputi akuntabilitas hukum dan kejujuran, akuntabilitas manajerial, akuntabilitas kebijakan, dan akuntabilitas keuangan (Artini et al., 2014). Dengan adanya asimetri informasi yang merupakan salah satu problematika utama dalam penerapan teori keagenan, memungkinkan suatu organisasi publik untuk tidak melaporkan keadaan organisasinya secara transparan atau cenderung melakukan kecurangan guna mengutamakan kepentingan individu atau organisasi 
yang bersangkutan. Hal ini bertolak belakang dengan dimensi akuntabilitas yang merupakan wujud pertanggungjawaban organisasi sektor publik kepada para pemangku kepentingan (stakeholders) yang salah satunya adalah masyarakat.

\section{Pengembangan Hipotesis \\ Pengaruh Moralitas Individu terhadap Kecurangan Akuntansi}

Menurut Ugrin et al., (2014) faktor keserakahan merupakan salah satu bentuk moralitas yang buruk dan dapat mendorong seseorang melakukan kecurangan. Seseorang yang dipenuhi sifat serakah cendurung tidak mempedulikan bagaimana cara memperoleh apapun yang diinginkannya.

Remisova et al. (2018) mengungkapkan bahwa kemampuan seseorang dalam menyelesaikan dilema etika dipengaruhi oleh tingkat penalaran moralnya. Seseorang dengan tingkat penalaran moral yang rendah akan berperilaku tidak sama dengan orang lain yang mempunyai tingkat penalaran moral yang tinggi, terutama ketika sedang menghadapi dilema etika. Seseorang yang mempunyai tingkat penalaran moral rendah akan berkecenderungan melakukan tindakan yang menguntungkan dirinya sendiri serta berusaha menghindari aktivitas yang dapat menimbulkan sanksi hukum. Sebaliknya, seseorang yang memiliki tingkat penalaran moral tinggi dalam perilakunya sehari-hari akan memperhatikan kepentingan orang-orang di sekelilingnya serta mendasarkan tindakannya pada prinsip-prinsip moral.

Sementara itu, Giammarco (2016) menyatakan bahwa tingkat penalaran moral seseorang berpengaruh pada perilaku etis mereka. Seseorang yang memiliki tingkat penalaran moral rendah akan berperilaku tidak sama dengan orang lain yang mempunyai tingkat penalaran moral yang tinggi ketika sedang menghadapi dilema etika. Didalam berperilaku, seseorang yang mempunyai tingkat penalaran moral rendah cenderung akan melakukan segala aktivitas yang menguntungkan dirinya sendiri serta berusaha untuk menghindari segala hal yang dapat mengakibatkan sanksi hukum.

Dalam teori level penalaran moral Kohlberg, individu dengan level penalaran rendah akan melakukan suatu tindakan didasari oleh hukum yang berlaku di lingkungannya, terlepas dari itu individu dengan penalaran moral rendah melakukan suatu tindakan atas dasar kepentingan pribadi. Di sisi lain, individu dengan level penalaran tinggi tidak akan melakukan kecurangan akuntansi meskipun dalam kondisi tidak terdapat sistem pengendalian internal karena individu menyadari bahwa kecurangan akuntansi tersebut merupakan perbuatan yang tidak etis dan dapat merugikan banyak pihak (Dellaportas, 2013). Hal ini sejalan dengan hasil penelitian Eliza (2015) dan Latan et al. (2016) yang menunjukkan adanya pengaruh negatif antara moralitas individu dengan kecurangan akuntansi. Berdasarkan kerangka pemikiran tersebut maka disusun hipotesis sebagai berikut:

$\mathrm{H}_{1}$ : Moralitas individu berpengaruh negatif terhadap kecurangan akuntansi.

\section{Pengaruh Sistem Pengendalian Internal terhadap Kecurangan Akuntansi}

Setiap institusi memiliki kewajiban untuk mengawasi kondisi dan pengelolaan serta menjaga seluruh aktivitas operasi dengan suatu sistem pengendalian yang baik (Ratnayani et al., 2014). Sistem Pengendalian Internal (SPI) di perguruan tinggi secara umum telah dikembangkan sesuai dengan tujuannya untuk memberikan jaminan bahwa aset organisasi dikelola sedemikian rupa sehingga dapat mendukung tercapainya tujuan organisasi (Aryanto et al., 2013). Hal ini menunjukkan bahwa suatu sistem pengendalian internal merupakan salah satu bentuk upaya preventif dalam menanggulangi kecurangan (fraud) dan mencapai tujuan organisasi. Sementara itu, Udayani dan Sari (2017) mengungkapkan bahwa Sistem Pengendalian Internal dapat mengurangi munculnya aktivitas menyimpang 
yang dilakukan oleh pihak manajemen. Apabila pengendalian internal suatu entitas tidak berjalan dengan baik, dan semua prosedur tidak dijalankan sebagaimana mestinya, maka akan memberikan kesempatan kepada para pegawai yang terlibat dalam kegiatan operasional organisasi untuk melakukan kecurangan.

Penerapan sistem pengendalian internal, menjadi sebuah upaya pencegahan yang dapat memperkecil peluang seseorang melakukan tindak kecurangan akuntansi untuk kepentingan dirinya sendiri maupun kelompoknya, yang mana hal ini akan merugikan pihak lain yang berkepentingan (Badara dan Saidin, 2013). Hal ini sejalan dengan penelitian Najahningrum (2013) dan Shintadevi (2015 yang menunjukkan adanya pengaruh negatif antara sistem pengendalian internal dengan kecurangan akuntansi. Berdasarkan kerangka pemikiran tersebut maka disusun hipotesis sebagai berikut:

$\mathrm{H}_{2}$ : Sistem pengendalian internal berpengaruh negatif terhadap kecurangan akuntansi.

\section{Pengaruh Asimetri Informasi terhadap Kecurangan Akuntansi}

Asimetri informasi timbul karena manajer sebagai agen mempunyai informasi lebih banyak dibanding pemilik (prinsipal) tentang segala kondisi dan situasi internal perusahaan serta keberlanjutan perusahaan pada masa yang akan datang. Menurut teori keagenan yang sudah mulai berkembang sejak tahun 1970, dikatakan bahwa dalam kegiatan operasional di suatu perusahan sangat mungkin terjadi asimetri informasi karena manajer mempunyai peran aktif dalam segala kegiatan perusahaan, sehingga segala informasi internal dengan mudah dapat diperoleh. Ketika informasi tersebut disampaikan tidak sesuai dengan keadaan yang sebenarnya kepada pihak prinsipal yang pada umumnya demi kepentingan manajemen, maka disinilah telah terjadi asimetri informasi. Rahim dan Stevens (2018) menyatakan bahwa asimetri informasi muncul dalam teori keagenan. Sedangkan Breeden dan Viswanathan (2016) menyatakan bahwa asimetri informasi merupakan suatu kondisi dimana terdapat ketidak seimbangan informasi yang dimiliki antara agen dengan prinsipal yang disebabkan oleh distribusi informasi yang tidak sama diantara keduanya. Menurut Ndofor et al., (2013) jika terjadi kesenjangan antara pihak pengguna dan pihak pengelola, hal tersebut dapat membuka peluang bagi pihak pengelola untuk melakukan kecurangan. Kecurangan akuntansi dapat terjadi saat manajer tidak memberikan informasi yang memadai untuk pengambilan keputusan dan atau melanggar kontrak yang telah disepakati sebelumnya. Beberapa penelitian terdahulu yang dilakukan oleh Aranta (2013); Prawira et al. (2014) dan Indriastuti et al. (2016) memberikan bukti empiris bahwa asimetri informasi berpengaruh positif terhadap kecurangan akuntansi. Berdasarkan kerangka pemikiran tersebut maka disusun hipotesis sebagai berikut:

$\mathrm{H}_{3}$ : Asimetri informasi berpengaruh positif terhadap kecurangan akuntansi.

\section{METODE PENELITIAN}

\section{Penentuan Populasi dan Sampel}

Populasi dalam penelitian ini adalah karyawan perguruan tinggi di Daerah Istimewa Yogyakarta. Sedangkan sampel penelitian adalah karyawan bagian keuangan pada beberapa universitas terkemuka di Yogyakarta, meliputi: (1) Universitas Gadjah Mada, (2) Universitas Negeri Yogyakarta, (3) Universitas Islam Negeri Yogyakarta, (4) Universitas Pembangunan Negara Yogyakarta, (5) Universitas Islam Indonesia, (6) Universitas Muhammadiyah Yogyakarta, dan (7) Universitas Sanata Dharma. Alasan memilih universitas di Yogyakarta karena Yogyakarta merupakan kota pelajar dimana banyak terdapat perguruan tinggi besar yang bereputasi nasional bahkan internasional, sehingga dapat dijadikan tolok ukur yang representatif terhadap perguruan tinggi di Indonesia. Pengumpulan data dilakukan selama bulan Oktober sampai 
dengan Desember tahun 2017 dengan menggunakan kuisioner dalam menghimpun persepsi para responden terkait faktor-faktor yang mempengaruhi kecurangan akuntansi di perguruan tinggi. Kuisioner penelitian ini terdiri dari beberapa pernyataan dan contoh kasus yang harus diisi berdasarkan persepsi para responden.

\section{Definisi Operasional dan Pengukuran Variabel \\ Moralitas Individu}

Moralitas individu merupakan suatu bentuk kesadaran seseorang untuk melakukan sesuatu yang baik berdasarkan peraturan yang berlaku dan memiliki kesadaran untuk berbuat baik karena seseorang menyadari hal tersebut adalah suatu hal yang harus dilakukan (Meindl et al., 2015). Lebih lanjut Puspasari dan Suwardi (2012) menyatakan bahwa seseorang yang mempunyai penalaran moral yang tinggi cenderung tidak akan melakukan kecurangan, baik dalam kondisi terdapat elemen pengendalian internal maupun dalam kondisi tidak terdapat elemen pengendalian internal. Indikator yang digunakan untuk mengukur variabel moralitas individu berdasarkan Kurniawan (2013) meliputi penyalahgunaan jabatan yang telah diberikan (tidak berperilaku sesuai dengan pedomannya) serta keserakahan (greed) yang merupakan faktor pemicu tindakan kecurangan kecurangan (fraud).

\section{Sistem Pengendalian Internal}

Suatu sistem pengendalian internal (SPI) merupakan sebuah alat atau cara yang digunakan oleh suatu organisasi untuk mencapai tujuannya (Arjalies dan Mundy, 2013). Pada dasarnya, sebuah organisasi didirikan tentu dengan sebuah tujuan dan cita-cita yang hendak dicapai, namun pada kenyataannya proses untuk mencapai tujuan organisasi tidaklah mudah. Bukan mustahil dalam proses tersebut terdapat banyak kendala yang dihadapi oleh suatu organisasi, baik yang berasal dari pihak internal maupun eksternal. Keefektifan pengendali- an internal juga merupakan salah satu faktor yang mempengaruhi adanya kecurangan akuntansi serta perilaku tidak etis (Donelson et al., 2017). Pengendalian internal menjadi kunci utama dalam organisasi untuk menekan terjadinya tindakan kecurangan. Pengendalian internal yang efektif akan mencegah terjadinya perilaku yang tidak etis serta perilaku curang dalam praktik akuntansi.

Dalam penelitian ini indikator yang digunakan untuk mengukur sistem pengendalian internal diperoleh dari komponen pengendalian intern yang dirumuskan oleh Committee of Sponsoring Organizatitons (COSO), meliputi: (1) Lingkungan Pengendalian, (2) Perhitungan Risiko, (3) Informasi dan Komunikasi, (4) Aktivitas Pengendalian, dan (5) Monitoring (Mutnuru, 2016).

\section{Informasi Asimetri}

Informasi asimetri merupakan kondisi dimana agen tidak menyampaikan informasi secara transparan dan akuntabel kepada prinsipal atas dasar kepentingannya pribadi (Billett et al., 2017). Hal ini disebabkan dalam praktiknya, agen memiliki peran secara aktif dalam kegiatan operasional perusahaan sehingga informasi internal perusahaan dapat dengan mudah diperoleh.

Indikator yang digunakan dalam penelitian ini menggunakan instrumen yang di kembangkan oleh Dunk (1993) meliputi: (1) Penyaji memiliki informasi yang lebih banyak, (2) penyaji lebih mengenal hubungan input-output, (3) penyaji lebih mengetahui apa yang sebenarnya dapat dicapai, (4) penyaji lebih mengenal teknis pekerjaan, (5) penyaji lebih mengetahui pengaruh faktor eksternal, dan (6) penyaji lebih mengetahui potensi kinerja.

\section{Kecurangan Akuntansi}

Tindak kecurangan (fraud) dapat didefinisikan sebagai suatu salah saji dari suatu fakta yang bersifat material yang diketahui tidak benar atau dilakukan dengan sengaja, dengan maksud menipu terhadap pihak lain yang mengakibatkan pihak lain 
dirugikan (Huber, 2016). Kecurangan akuntansi menjadi variabel dependen yang diukur dengan menggunakan indikator yang digunakan oleh Najahringrum (2013) serta Kusuma dan Andreina (2017) diantaranya: (1) kecurangan laporan keuangan, (2) penyalahgunaan aset, dan (3) Korupsi.

Pengukuran terhadap variabel-variabel penelitian ini menggunakan skala likert 1-5 (Sangat Setuju, Setuju, Netral, Tidak Setuju, Sangat Tidak Setuju), kecuali pada variabel moralitas individu nomor 10-13 skala perhitungannya dibalik menjadi 5-1.

\section{ANALISIS DAN PEMBAHASAN}

Pada Tabel 1 dapat dilihat komposisi responden penelitian. Terdapat tujuh perguruan tinggi besar di Daerah Istimewa Yogyakarta. Masing-masing perguruan tinggi tersebut diwakili oleh lebih dari 10 responden kecuali Universitas Muhammadiyah Yogyakarta dan Universitas Sanata Dharma karena beberapa kuisionernya tidak lengkap. Jumlah total responden yang digunakan dalam penelitian ini 86 orang.

Pada Tabel 2 terlihat bahwa penilaian terhadap variabel diukur dengan skor terendah 1 dan tertinggi 5 dengan kategori berdasarkan masing-masing variabel, sehingga interval tingkat persepsi dapat dihitung sebagai berikut: 5-1/5=0,80.

Tabel 1

Rincian Jumlah Responden per-Perguruan Tinggi

\begin{tabular}{lcc}
\hline \multicolumn{1}{c}{ Nama Perguruan Tinggi } & Jumlah & Persentase \\
\hline Universitas Gadjah Mada & 12 & $14.0 \%$ \\
Universitas Negeri Yogyakarta & 15 & $17.4 \%$ \\
Universitas Islam Negeri Yogyakarta & 15 & $17.4 \%$ \\
Universitas Pembangunan Nasional & 14 & $16.3 \%$ \\
Universitas Islam Indonesia & 15 & $17.4 \%$ \\
Universitas Muhammadiyah Yogyakarta & 6 & $7.0 \%$ \\
Universitas Sanata Dharma & 9 & $10.5 \%$ \\
\hline
\end{tabular}

Sumber: Data primer diolah, 2019

Tabel 2

Deskriptif Variabel Penelitian

\begin{tabular}{lccccl}
\hline \hline & n & Min & Maks & Rata-rata & Std Dev \\
\hline Kecurangan Akuntansi $(Y)$ & 86 & 1,00 & 4,00 & 1,6512 & 0,68199 \\
Moralitas Individu $\left(\mathrm{X}_{1}\right)$ & 86 & 1,00 & 5,00 & 3,6977 & 0,88211 \\
Sistem Pengendalian Internal $\left(\mathrm{X}_{2}\right)$ & 86 & 2,00 & 5,00 & 4,2791 & 0,71375 \\
Asimetri Informasi $\left(\mathrm{X}_{3}\right)$ & 86 & 1,00 & 5,00 & 3,4070 & 1,06691 \\
\hline
\end{tabular}

Sumber: Data primer diolah, 2019

Berdasarkan interval ini maka setiap variabel dijelaskan berdasarkan batasan persepsinya yang dapat dijelaskan pada Tabel 3 berikut ini.

Berdasarkan pengolahan statistik deskriptif dapat kita ketahui bahwa penilaian dari 86 responden terhadap kasus ke- curangan akuntansi adalah sangat jarang terjadi. Hal ini ditunjukkan dengan nilai rata-rata 1,6512 pada Tabel 2 yang berada pada interval 1,00-1,80. Hal ini berarti kecurangan pada instansi tempat responden bekerja termasuk dalam kategori sangat jarang terjadi. 
Tabel 3

Batasan Persepsi Kecurangan Akuntansi

\begin{tabular}{cl}
\hline \hline Interval & \multicolumn{1}{c}{ Keterangan } \\
\hline $1,00-1,80$ & Sangat jarang terjadi \\
$1,81-2,60$ & Jarang terjadi \\
$2,61-3,40$ & Kadang-kadang terjadi \\
$3,41-4,20$ & Sering terjadi \\
$4,21-5,00$ & Sangat sering terjadi \\
\hline
\end{tabular}

Sumber: Data diolah, 2019.

Tabel 4

Batasan Persepsi Moralitas Individu

\begin{tabular}{cc}
\hline \hline Interval & Keterangan \\
\hline $1,00-1,80$ & Sangat Buruk \\
$1,81-2,60$ & Buruk \\
$2,61-3,40$ & Cukup Baik \\
$3,41-4,20$ & Baik \\
$4,21-5,00$ & Sangat Baik \\
\hline
\end{tabular}

Sumber: Data diolah, 2019.

Sementara itu, terkait dengan penilaian terhadap moralitas individu, dapat dikatakan bahwa responden penelitian ini mempunyai moralitas individu yang baik. Hal ini dapat ditunjukkan dengan nilai ratarata pada Tabel 3 sebesar 3,6977 dimana nilai ini berada pada interval 3,41-4,20, yang artinya responden mempunyai moralitas yang baik, sehingga cenderung menolak terjadinya kecurangan akuntansi. Namun demikian, nilai minimum variabel moralitas individu sebesar 1,00, ini mengandung arti bahwa ada responden yang setuju jika suatu saat terjadi kecurangan akuntansi. Dengan demikian dapat diperkirakan bahwa dalam instansi yang bersangkutan kecurangan akuntansi merupakan hal yang masih mendapat toleransi dari responden.

Pada Tabel 5 dapat dilihat bahwa, penilain responden terhadap sistem pengendalian internal di instansinya sangat efektif. Hal ini dilihat dari nilai rata-ratanya sebesar 4,2791 dimana nilai ini masuk dalam katagori sangat efektif. Hal ini berarti sistem pengendalian internal yang diterapkan dalam instansi para responden sangat efektif untuk mengantisipasi terjadinya kecurangan akuntansi. Akan tetapi, nilai minimum variabel ini sebesar 2,00, artinya masih terdapat responden yang menyatakan bahwa sistem pengendalian internal di instansinya belum dijalankan secara efektif.

Tabel 5

Batasan Persepsi Sistem Pengendalian Internal

\begin{tabular}{cc}
\hline Interval & Keterangan \\
\hline $1,00-1,80$ & Sangat Tidak Efektif \\
$1,81-2,60$ & Tidak Efektif \\
$2,61-3,40$ & Cukup Efektif \\
$3,41-4,20$ & Efektif \\
$4,21-5,00$ & Sangat Efektif \\
\hline
\end{tabular}

Sumber: Data diolah, 2019. 
Tabel 6

Batasan Persepsi Asimetri Informasi

\begin{tabular}{cc}
\hline \hline Interval & Keterangan \\
\hline $1,00-1,80$ & Asimetri Sangat Rendah \\
$1,81-2,60$ & Asimetri Rendah \\
$2,61-3,40$ & Cukup Asimetri \\
$3,41-4,20$ & Asimetri Tinggi \\
$4,21-5,00$ & Asimetri Sangat Tinggi \\
\hline
\end{tabular}

Sumber: Data diolah, 2019.

Lebih lanjut dalam Tabel 6 dapat diketahui bahwa persepsi responden penelitian ini terhadap asimetri informasi pada instansinya adalah asimetri tinggi. Hal ini terlihat dengan nilai rata-ratanya sebesar 3,4070 yang mana angka tersebut pada Tabel 6 termasuk dalam kategori asimetri tinggi. Sementara itu, nilai minimum variabel asimetri informasi sebesar 1,00. Hal ini berarti masih ada responden yang mempunyai persepsi bahwa asimetri informasi tidak boleh terjadi pada instansi mereka, hal tersebut memberikan dorongan kepada responden untuk lebih transparan dalam memberikan informasi sehingga tidak mengakibatkan asimetri informasi.

Hasil pengujian statistik deskriptif terhadap variabel dependen yaitu kecurangan akuntansi dan variabel independen yang meliputi moralitas individu, Sistem Pengendalian Internal, dan informasi asimetri ditunjukkan pada Tabel 7 berikut.

Tabel 7

Hasil Uji Analisis Deskriptif

\begin{tabular}{lccccc}
\hline & n & Min & Max & Mean & Std. Dev \\
\hline Kecurangan Akuntansi & 86 & 1,00 & 4,00 & 1,6512 & 0,98199 \\
Moralitas Individu & 86 & 1,00 & 5,00 & 3,6977 & 0,88211 \\
SPI & 86 & 2,00 & 5,00 & 4,2791 & 0,71375 \\
Informasi Asimetri & 86 & 1,00 & 5,00 & 3,4070 & 1,06691 \\
\hline
\end{tabular}

Sumber: Data diolah, 2019.

Dilihat dari hasil analisis deskriptif pada Tabel 7, semua variabel mempunyai nilai rata-rata lebih besar dari standar deviasinya. Hal ini berarti bahwa semua data bersifat homogen.

\section{Uji Hipotesis (Uji t)}

Sebelum dilakukan uji regresi, dalam penelitian ini telah dilakukan uji kualitas data terlebih dahulu sebagai syarat dilakukannya analisis regresi. Setelah semua data dinyatakan telah memenuhi syarat pengujian regresi, selanjutnya dilakukan uji regresi berganda. Tabel 8 menunjukkan hasil analisis regresi linier berganda penelitian ini.

Dari hasil analisis regresi linier berganda pada Tabel 8 tersebut, maka diperoleh sebuah persamaan tentang faktor-faktor yang mempengaruhi kecurangan akuntansi di perguruan tinggi sebagai berikut:

$$
\mathrm{Y}=5,145-0,416 \mathrm{MI}-0,426 \mathrm{SPI}-0,034 \mathrm{IA}
$$

\section{a. Moralitas Individu}

Hipotesis pertama yang diajukan dalam penelitian ini adalah moralitas individu berpengaruh negatif terhadap kecurangan akuntansi. Hal ini mengandung pengertian bahwa semakin baik moralitas individu dalam sebuah instansi maka semakin rendah kecurangan akuntansi di instansi tersebut dalam hal ini di perguruan tinggi.

Hasil pengujian dalam penelitian ini menunjukkan bahwa nilai koefisien variabel 
moralitas individu (MI) adalah $-0,416$ dan probabilitas ( $p$-value) sebesar 0,000 yang berarti $p$-value $<0,05$. Dengan demikian hipotesis pertama $\left(\mathrm{H}_{1}\right)$ didukung.

Tabel 8

Analisis Regresi Linier Berganda

\begin{tabular}{|c|c|c|c|}
\hline Variabel & $\begin{array}{c}\text { Koefisien } \\
\text { Regresi }\end{array}$ & $\begin{array}{c}\text { Sig-t } \\
\text { (p-value) }\end{array}$ & Keterangan \\
\hline Konstanta & 5.145 & 0,000 & \\
\hline Moralitas Individu (MI) & -0.416 & 0.000 & $\mathrm{H}_{1}$ didukung \\
\hline Sistem Pengendalian Internal (SPI) & -0.426 & 0.002 & $\mathrm{H}_{2}$ didukung \\
\hline Informasi Asimetri (IA) & -0.034 & 0.591 & $\mathrm{H}_{3}$ tidak didukung \\
\hline F-Hitung $\quad: 19.322$ & & & \\
\hline : 0.000 & & & \\
\hline Adjusted R Square : 0.442 & & & \\
\hline
\end{tabular}

Sumber: Data diolah, 2019.

Hasil penelitian ini sejalan dengan penelitian yang dilakukan oleh Aranta (2013) dan Eliza (2015) yang mengungkapkan bahwa moralitas aparat berpengaruh negatif terhadap kecurangan akuntansi, sehingga semakin baik moral seseorang maka kecurangan akuntansi akan semakin menurun. Lebih lanjut Pierre et al. (2016) dalam penelitiannya juga mengungkapkan bahwa seseorang akan mengambil keputusan yang baik karena memiliki kesadaran akan kewajiban dan tanggung jawabnya, bukan atas dasar pendapatan atau keuntungan yang ingin diperolehnya. Oleh sebab itu moralitas individu merupakan sikap atau perbuatan baik yang dilakukan tanpa mengharapkan imbalan.

Selain itu, Puspasari dan Suwardi (2012) melakukan penelitian serupa mengenai pengaruh moralitas individu terhadap kecurangan akuntansi pada konteks pemerintah daerah dan memperoleh hasil bahwa individu yang memiliki penalaran moral tinggi cenderung tidak melakukan kecurangan akuntansi bahkan pada kondisi tidak terdapat pengendalian internal sekalipun. Hasil penelitian ini juga mendukung pernyataan Kohlberg dan Kramer (1969) serta Sudarshan (2014) yang menyatakan bahwa semakin tinggi level penalaran moral individu maka semakin rendah melakukan kecurangan, karena individu dengan moralitas yang baik tidak akan mementingkan kepentingan pribadinya dalam melakukan suatu perbuatan dan bertindak sesuai dengan hukum-hukum yang lebih universal, tidak hanya sebatas pada peraturan pada suatu organisasi atau masyarakat. Sehubungan dengan hal tersebut, pengelola perguruan tinggi seyogyanya melakukan berbagai program yang membawa dampak peningkatan moral pegawainya baik secara formal maupun informal di perguruan tingginya masingmasing. Terkait dengan hal tersebut Cruz (2018) menyatakan bahwa program peningkatan moral di perguruan tinggi dapat dimulai dari sistem rekruitmen yang baik. Dari sini akan terjaring bibit-bibit dan calon karyawan kompeten yang dibutuhkan oleh perguruan tinggi. Dengan sistem rekrutmen yang tepat, maka secara tidak langsung perguruan tinggi yang bersangkutan dapat memperoleh karyawan dengan moral, etika dan etos kerja yang optimal.

Lebih lanjut Elnaga dan Imran (2013) mengungkapkan bahwa salah satu cara yang dapat dipakai perusahaan untuk meningkatkan moral karyawan yaitu melalui pelatihan yang dilakukan oleh tim Human Resource Development (HRD). Pelatihan yang dimaksud tidak hanya pelatihan teknis saja, 
melainkan pelatihan yang bersifat psikologis, dimana sangat penting dalam upaya meningkatkan etos kerja dan moral para karyawan. Selain itu, Peng dan Wei (2018) serta Elsetouhi et al. (2018) menambahkan bahwa untuk menjaga moral yang baik para karyawan, pimpinan lembaga harus bisa memberi contoh yang baik kepada para karyawan. Hal ini karena para karyawan akan mengacu perilaku pimpinanya selama menjalankan pekerjaannya. Ketika beberapa hal tersebut dilakukan, diharapkan akan menekan segala tindak kecurangan di lingkungan perguruan tinggi, khususnya kecurangan akuntansi yang saat ini marak terjadi.

\section{b. Sistem Pengendalian Internal}

Hipotesis kedua yang diajukan dalam penelitian ini adalah sistem pengendalian internal berpengaruh negatif terhadap kecurangan akuntansi. Hal ini mengandung pengertian bahwa semakin efektif suatu sistem pengendalian internal dalam sebuah instansi, maka semakin rendah kecurangan akuntansi di instansi tersebut. Hasil pengujian signifikansi menunjukkan nilai koefisien variabel sistem pengendalian internal (SPI) sebesar $-0,426$ dan probabilitas (p-value) sebesar 0,002. Dengan demikian hipotesis kedua $\left(\mathrm{H}_{2}\right)$ didukung.

Hasil penelitian ini sejalan dengan penelitian Najahningrum (2013) serta Prawira et al., (2014) yang menunjukkan hasil bahwa keefektifan sistem pengendalian internal berpengaruh negatif terhadap kecurangan akuntansi. Dengan demikian semakin efektif suatu sistem pengendalian internal, maka kecurangan akuntansi akan semakin menurun. Sama halnya dengan penelitian yang dilakukan Prawira et al. (2014) bahwa efektivitas sistem pengendalian internal berpengaruh negatif terhadap kecurangan akuntansi.

Landasan teori yang mendasari hipotesis ini adalah teori Fraud Triangle yang dikembangkan oleh Cressey (1953). Dalam Fraud Triangle disebutkan bahwa salah satu faktor penyebab seseorang melakukan ke- curangan adalah kesempatan (opportunity). Adanya kesempatan memungkinkan seseorang untuk melakukan kecurangan. Pada sebuah instansi atau perusahaan, tanpa adanya pengendalian yang baik akan memberikan kesempatan kepada seseorang untuk leluasa melakukan kecurangan. Dengan demikian, adanya suatu sistem pengendalian internal dalam sebuah instansi merupakan bentuk upaya pencegahan (preventif) sehingga dapat menekan terjadinya tindak kecurangan akuntansi (fraud).

Teori keagenan yang dikembangkan oleh Jensen dan Meckling (1976) menyebutkan bahwa salah satu permasalahan yang sering terjadi pada sebuah organisasi adalah terjadinya kesenjangan informasi antara agen yang diberi kepercayaan untuk mengelola organisasi dengan prinsipal atau pemegang saham. Berkenaan dengan hal tersebut Cram et al., (2016) menyatakan bahwa kesenjangan informasi ini dapat diminimalisasi dengan adanya pengendalian internal yang efektif. Dengan demikian hasil penelitian ini juga sejalan dengan konsep teori keagenan, yakni dengan adanya sistem pengendalian internal yang efektif, akan mempersempit kesempatan seseorang dalam melakukan kecurangan, sehingga semakin efektif sistem pengendalian internal, semakin kecil terjadinya kecurangan akuntansi.

\section{c. Informasi Asimetri}

Hipotesis ketiga yang diajukan dalam penelitian ini adalah informasi asimetri berpengaruh positif terhadap kecurangan akuntansi. Artinya, semakin tinggi terjadinya informasi asimetri dalam sebuah instansi, semakin tinggi pula kecurangan akuntansi pada instansi tersebut. Hasil pengujian pada penelitian ini menunjukkan nilai koefisien variabel informasi asimetri (IA) sebesar -0,034 dan probabilitas ( $p$-value) sebesar 0,591. Dengan demikian hipotesis ketiga $\left(\mathrm{H}_{3}\right)$ tidak didukung.

Hasil penelitian ini sejalan dengan penelitian yang dilakukan oleh Aryanto et al., (2013) pada suatu lembaga pendidikan 
negeri di Jakarta yang menunjukkan bahwa informasi asimetri tidak berpengaruh terhadap kecurangan akuntansi. Akan tetapi, penelitian ini bertentangan dengan penelitian Najahningrum (2013) di beberapa dinas pemerintah provinsi Daaerah Istimewa Yogyakarta, serta Prawira et al., (2014) yang dilakukan di beberapa BUMD kabupaten Buleleng, dimana kedua penelitian tersebut membuktikan bahwa informasi asimetri berpengaruh positif terhadap kecurangan akuntansi. Adanya perbedaan tersebut kemungkinan disebabkan oleh perbedaan karakteristik organisasi, dimana organisasi pendidikan yang didukung dengan teknologi informasi yang baik dan sumber daya manusia yang terlatih mengakibatkan akses informasi ke segala unitnya lebih lancar sehingga kemungkinan terjadi asimetri informasi sangat kecil. Sementara itu, akses informasi pada lembaga di pemerintah daerah kemungkinan belum maksimal sehingga potensi terjadi asimetri informasi tinggi.

Landasan teori yang mendasari hipotesis penelitian ini adalah teori keagenan dari Jensen dan Meckling (1976) yang mendefinisikan hubungan keagenan sebagai kontrak antara satu orang atau lebih yang bertindak sebagai prinsipal yang menunjuk orang lain sebagai agen untuk melakukan suatu jasa tertentu untuk kepentingan prinsipal, termasuk mendelegasikan kekuasaan dalam pembuatan keputusan. Dalam praktiknya, teori keagenan memiliki kelemahan seperti peluang terjadinya asimetri informasi (Pepper dan Gore, 2015). Agen yang diberikan kewenangan menjalankan aktivitas bisnis perusahaan dapat melakukan kecurangan untuk kepentingannya sendiri dengan memanipulasi informasi dan membatasi informasi yang diberikan kepada pihak prinsipal.

Hasil penelitian ini menunjukkan bahwa nilai koefisiean variabel asimetri informasi adalah $-0,034$ (negatif), artinya variabel asimetri informasi memiliki arah yang berlawanan (negatif) terhadap kecurangan akuntansi. Hal ini kemungkinan disebabkan implementasi sistem informasi manajemen pada perguruan tinggi di Yogyakarta pada umumnya sudah sangat baik, sehingga informasi akuntansi terdistribusi dengan baik pada setiap bagian di lingkungan perguruan tinggi. Dengan kata lain aspek transparansi telah dijalankan dengan baik oleh para pengelola perguruan tinggi. Pemikiran hal ini berdasarkan fakta bahwa Yogyakarta sebagai kota pelajar, dimana perguruan tinggi yang bereputasi nasional bahkan internasional terdapat di kota ini.

Leonard et al., (2004) dan Jia et al. (2018) menyatakan bahwa kualitas pelaksanaan sistem informasi manajemen pada sebuah organisasi sangat mempengaruhi perilaku yang baik kepada para pegawainya. Lebih lanjut $\mathrm{Wu}$ et al., (2015) menyatakan bahwa semakin baik sistem informasi manajemen akan semakin baik pula kualitas tatakelola organisasi, dengan demikian potensi terjadinya informasi asimetri pada perguruan tinggi yang menjadi obyek penelitian ini sangat rendah.

Selain hal tersebut di atas, hasil penelitian ini mengindikasikan bahwa para pegawai bagian keuangan perguruan tinggi yang menjadi obyek penelitian memiliki persepsi bahwa informasi yang dimiliki dan berkaitan dengan kepentingan publik harus disampaikan secara transparan kepada publik atau masyarakat. Hal ini sejalan dengan pendapat Mardiasmo (2016) yang menyatakan bahwa perguruan tinggi merupakan salah satu domain publik yang memiliki tanggung jawab untuk melaporkan hasil operasi dan dana publik. Oleh karena itu, perguruan tinggi sebagai salah satu organisasi sektor publik harus menyediakan informasi secara transparan dan akuntabel sehingga tidak terjadi kesenjangan informasi atau informasi asimetri.

\section{SIMPULAN DAN SARAN Simpulan}

Berdasarkan hasil analisis yang telah dilakukan, dapat disimpulkan bahwa variabel moralitas individu berpengaruh 
negatif terhadap kecurangan akuntansi pada perguruan tinggi di Daerah Istimewa Yogyakarta, sehingga jika moralitas individu semakin baik maka kecurangan akuntansi akan menurun. Begitu juga sebaliknya, jika moralitas individu buruk maka kecurangan akuntansi akan meningkat. Hal ini mengandung pengertian bahwa kualitas moral individu yang semakin baik akan mencegah seseorang untuk melakukan tindakan kecurangan. Hal ini karena tingkat moralitas yang tinggi akan mendorong seseorang untuk taat kepada aturan dan melakukan berbagai tindakan positif yang bermanfaat bagi orang lain.

Penelitian ini juga dapat membuktikan bahwa variabel sistem pengendalian internal berpengaruh negatif terhadap kecurangan akuntansi pada perguruan tinggi di Daerah Istimewa Yogyakarta, sehingga jika sistem pengendalian internal berjalan efektif maka kecurangan akuntansi akan menurun. Begitu juga sebaliknya, jika sistem pengendalian internal berjalan tidak efektif maka kecurangan akuntansi akan meningkat. Hal ini sebagai bukti bahwa sistem pengendalian internal yang kuat dan handal dapat mengurangi kesempatan dilakukannya tindakan yang melanggar aturan atau tindakan kecurangan.

Sementara itu, variabel informasi asimetri tidak berpengaruh secara signifikan terhadap kecurangan akuntansi pada perguruan tinggi di Daerah Istimewa Yogyakarta, sehingga tinggi rendahnya informasi asimetri tidak berpengaruh terhadap kecurangan akuntansi. Hal ini mengindikasikan bahwa aspek transparansi telah dijalankan dengan baik oleh para pengelola perguruan tinggi di Daerah Istimewa Yogyakarta, sehingga distribusi informasi khususnya informasi akuntansi telah dijalankan dengan baik. Hal ini mengakibatkan variabel informasi asimetri pada penelitian ini tidak bisa menjadi prediktor terhadap kecurangan akuntansi pada perguruan tinggi, khususnya perguruan tinggi di Daerah Istimewa Yogyakarta.

\section{Saran}

Dalam penelitian ini variabel moralitas individu dan sistem pengendalian internal berpengaruh negatif terhadap kecurangan akuntansi di lingkungan perguruan tinggi. Sehubungan dengan hal tersebut, para pengelola perguruan tinggi diharapkan dapat meningkatkan moralitas individu setiap pegawai bagian keuangan misalnya dengan melakukan sistem rekruitmen yang berkualitas; melakukan pembinaan, pelatihan dan pengarahan terkait dengan kinerja karyawan; pimpinan memberikan contoh berperilaku yang baik; serta usaha lainnya yang akan mendorong ketaatan pegawai terhadap peraturan, dan pada akhirnya akan tertanam moral yang baik. Selain itu, pengelola perguruan tinggi seyogyanya juga dapat mengoptimalkan sistem pengendalian internal yang diterapkan di lingkungannya agar kecurangan akuntansi dapat diminimalisasi dengan baik.

Disamping hal tersebut, terkait dengan penelitian-penelitian yang akan datang diharapkan diperluas cakupan wilayah penelitian, serta menambah variabel potensial lain yang dapat dijadikan prediktor terhadap tindakan kecurangan akuntansi di lingkungan perguruan tinggi, seperti budaya organisasi, sistem kompensasi, penegakan peraturan, dan variabel lainnya.

\section{DAFTAR PUSTAKA}

Agrawal. A., dan T. Cooper. 2015. Insider trading before accounting scandals. Journal of Corporate Finance 34(1): 169190.

Aranta, P. Z. 2013. Pengaruh moralitas aparat dan asimetri informasi terhadap kecurangan akuntansi (Studi pada Pemerintah Kota Sawahlunto). Jurnal Akuntansi 1 (1): 160.

Arjalies, D.L., dan J. Mundy. 2013. The use of management control systems to manage CSR strategy: A levers of control perspective. Management Accounting Research 24 (4): 284-300.

Artini, N .L. E. A., M. D. Adiputra., dan N. T. Herawati. 2014. Pengendalian internal 
terhadap kecenderungan kecurangan akuntansi pada satuan kerja perangkat daerah. E-Journal Universitas Pendidikan Ganesha 2 (1): 47-63.

Aryanto, M.S., T.H. Utaminingtyas., dan R. Anggraini. 2013. Pengaruh sistem pengendalian internal, sistem kompensasi, dan asimetri informasi dalam kecenderungan kecurangan akuntansi. SNA XVI, 4770-4791.

Auriol, E., S. Straub, dan T. Flochel. 2016. Public procurement and rent-seeking: The case of Paraguay. World Development 77: 395-407.

Badara, M. S., dan S. Z. Saidin. 2013. Impact of the effective internal control system on the internal audit effectiveness at local government level. Journal of Social and Development Sciences 4(1): 16-23.

Barr, A., dan D.Serra. 2010. Corruption and culture: An experimental analysis. Journal of Public Economics (94): 862-869.

Billett, M.T., J.A. Garfinkel, dan M. Yu. 2017. The effect of asymmetric information on product market outcomes. Journal of Financial Economics 123(2): 357-376.

Breeden. D. T. dan S. Viswanathan. 2016. Why do firms hedge? An asymetric information model. The Journal Fixed Income 25(3): 7-25.

Cram, W. A., M. K. Brohman, Y. E. Chan dan R.B. Gallupe. 2016. Information systems control alignment: Complementary and conflicting systems development controls. Information and Management 53(2): 183-196.

Cressey, D. R. 1953. Other people's money: A study of the social psychology of embezzlement. Michigan: Free Press.

Cruz, A.C. 2018. Portal for employees in the public sector: A tool for knowledge management in human resources. Handbook of Research on Modernization and Accountability in Public Sector Management. IGI-Global. https:// www.igi-global.com/chapter/portalfor-employees-in-the-public-sector/ 199470. (accessed: November 13, 2018)

Dellaportas, S. 2013. Confersation with inmate accountants: Motivation, opportunity and the fraud triangle. Accounting Forum 37(1): 29-39.

Donelson, D.C., M.S. Ege. dan J.M. Mclnnis, 2017. Internal control weaknesses and financial reporting fraud. Auditing: A Journal of Practice 36(3): 45-69.

Dunk, A.S. 1993. The effects of job-related tension on managerial performance. Accounting, Organizations and Society 18(7-8): 575-586.

Eliza, Y. 2015. Pengaruh moralitas individu dan pengendalian internal terhadap kecenderungan kecurangan akuntansi. Jurnal Akuntansi 4: 86-100.

Elnaga, A. dan Imran, A. 2013. The effect of training on employee performance. European Journal of Business and Management 5(4): 137-147.

Elsetouhi, A. M., Hammad, A. A., Nagm, A, E, A. dan Elbaz, A. M. 2018. Perceived leader behavioral integrity and employee voice in SMEs travel agents: The mediating role of empowering leader behaviors. Tourism Management (65): 100-115.

Ghozali, I. 2005. Aplikasi Analisis Multivariate Dengan Program SPSS. Badan Penerbit Diponegoro. Semarang.

Giammarco, E. A. 2016. The measurement of individual differences in morality. Personality and Individual Differences (88): 26-34.

Huber, W. D. 2016. Forensic Accounting, Fraud Theory, and the End of the Fraud Triangle. Journal of Theoretical Accounting Research 12(2): 28-48.

Indriastuti, D. E., Agusdin dan Animah. 2016. Analisis pengaruh asimetri informasi, pengendalian internal, persepsi kesesuaian kompensasi, moralitas individu, dan ketaatan aturan akuntansi terhadap kecurangan akuntansi. Jurnal Infestasi 12(2): 115-130.

Jensen, M. C. dan W. H. Meckling. 1976. Theory of the firm: Managerial behavior, agency costs and ownership structure theory of the firm: Managerial behavior, agency costs and ownership 
structure. Journal of Financial Economics, 3 (4): 305-60. doi:http://dx.doi.org/ 10.1016/0304-405X(76)90026-X. (accessed: July 4, 2018).

Jia, L., Hall, D., Yan, Z., Liu, J. dan Byrd, T. 2018. The impact of relationship between IT staff and users on employee outcomes of IT users. Information Technology \& People, 31 (5), 986-1007. https://doi.org/10.1108/ITP-03-20170075. (accessed: October 10, 2018).

Johnson, W.C., W. Xie dan S. Yi. 2014. Corporate fraud and the value of reputations in the product market. Journal of Corporate Finance 25(1): 16-39.

Joseph, O.N., O. Albert, dan Byaruhanga, J. 2015. Effect of internal control on fraud detection and prevention in district treasuries of Kakamega county. International Journal of Business and Management Invention 4(1): 47-57.

Jusup, A. H. 2010. Auditing. Penerbitan STIE YKPN. Yogyakarta.

Kabar Korupsi. 2014. Pengelolaan aset perguruan tinggi negeri rawan terjerat kasus korupsi. kabarkorupsi.com (diakses pada, 22 Juni 2018).

Kassem, R. dan A. W. Higson. 2016. External auditor and corporate corruption: Implications for external audit regulators. Current Issues in Auditing10(1): 110.

Kerler, W.A. dan L.N. Killough. 2009. The effects of satisfaction with a client's management during a prior audit engagement, trust, and moral reasoning on auditors' perceived risk of management fraud. Journal of Business Ethics 85(2): 109-136.

Kohlberg. L. dan R. Kramer. 1969. Continuities and discontinuities in childhood and adult moral development. Human Development 12(1): 93-120.

Kurniawan, G. 2013. Pengaruh moralitas, motivasi dan sistem pengendalian intern terhadap kecurangan laporan keuangan (Studi empiris pada SKPD di kota Solok). Artikel Universitas Negeri Padang.
Kusuma, H. dan R. R. T. R. Andreina. 2017. Determinants of accounting frauds: Perceptions of Indonesian civil servants. International Journal of Research in Business \& Social Science 6(4): 11-21.

Latan, H., C. M. Ringle, dan C .J. C. Jabbour. 2016. Whistleblowing intentions among public accountants in Indonesia: Testing for the moderation effects. Journal of Business Ethics 152: 573-588.

Leonard, L. N. K., T. P. Cronan, dan J. Kreie. 2004. What influences IT ethical behavior intentions-planned behavior, reasoned action, perceived importance, or individual characteristics?. Information and Management 42(1): 143-158.

Mardiasmo. 2016. Pewujudan transparansi dan akuntabilitas publik melalui akuntansi sektor publik: Suatu sarana good governance. Akuntansi Pemerintah 2. Andi. Yogyakarta.

Maulidi, A. 2016. Dealing with fraudulent financial statement in business organizations through whistleblowing system and staff awareness of fraud. International Conference on Accounting Studies (ICAS), 15-18 August 2016, Langkawi, Kedah, Malaysia.

Meindl. P., E. Jayawicreme, R. M. Furr, dan W. Fleeson. 2015. A foundation beam for studying morality from a personological point of view: are individual differences in moral behaviors and thoughts consistent? Journal of Research in Personality 59: 8192.

Mutnuru, S. 2016. The role of internal controls on employees' engagement in small organizations. Journal of Business Studies Quarterly 7(4): 102-114.

Najahningrum, A. F. 2013. Faktor-faktor yang mempengaruhi fraud: Persepsi pegawai dinas provinsi DIY. Accounting Analysis Journal 2(3): 259-267.

Ndofor, H. A., C. Wesley, dan R. L. Priem. 2013. The effects of complexity-based information asymetries on financial reporting fraud. Journal of Management 41(6): 1774-1797. 
Nordiawan, D. 2006. Akuntansi Sektor Publik. Salemba Empat. Jakarta.

Peng, H. dan Wei, F. 2018. Trickle-down effects of perceived leader integrity on employee creativity: A moderated mediation model. Journal of Happiness Studies (150): 837-851.

Pepper, A. dan J. Gore. 2015. Behavioral Agency Theory: New Foundations for Theorizing About Executive Compensation. Journal of Management 41(4): 1045-1068.

Pierre, M. S., G. Hofinger and R. Simon. 2016. Strategies for Action: Ways to Achieve Good Decisions. Crisis Management in Acute Care Settings 2(1): 209-229.

Prawira, M. D., N. T. Herawati., dan N. A. S. Darmawan. 2014. Pengaruh moralitas individu, asimetri informasi dan efektivitas pengendalian internal terhadap kecenderungan kecurangan (fraud) akuntansi (Studi empiris pada Badan Usaha Milik Daerah kabupaten Buleleng). E-Journal S1 Ak Universitas Pendidikan Ganesha 2(1).

Puspasari, N., dan E. Suwardi. 2012. Pengaruh moralitas individu dan pengendalian internal terhadap kecendrungan kecurangan akuntansi: Studi eksperimen pada konteks pemerintah daerah. Jurnal SNA XV, 1-30.

Rahim. H. Y. A. dan D. E. Stevens. 2018. Information system precision and honesty in managerial reporting: A reexamination of information asymmetry effects. Accounting, Organizations and Society 64(1): 31-43.

Ratnayani, P., A. E. Sujana. dan N. A. S. Darmawan. 2014. Pengaruh pengendalian intern kas dan implememtasi good governance terhadap fraud (Studi empiris pada SKPD di Kabupaten Buleleng). E-Journal S1 Ak Universitas Pendidikan Ganesha 2(1).

Remisova, A., Lasakova, A. dan Kirchmayer, Z. 2018. Influence of formal ethics program components on managerial ethical behavior. Journal of Business Ethics (160): 151-166.
Roberts, M. R. 2015. The role of dynamic renegotiation and asymmetric information in financial contracting. Journal of Financial Economics 116(1): 61-81.

Sargiacomo, M., L. Lanni., A. D'Andreamattio dan S. Servalli. 2015. Accounting and the fight against corruption in Italian government procurement: A longitudinal critical analysis (19922014). Critical Perspectives on Accounting. 28: 89-96.

Shintadevi, P. F. 2015. Pengaruh keefektifan pengendalian internal, ketaatan aturan akuntansi dan kesesuaian kompensasi terhadap kecenderungan kecurangan akuntansi dengan perilaku tidak etis sebagai variabel intervening. Jurnal Nominal 4(2): 111-126.

Sudarshan. P. 2014. Of Mode of reasoning and context: Danish evidence of accounting student's moral reasoning abilities in resolving ethical dilemmas related to fraud. Research Repository University of Essex. http://repository. essex.ac.uk/9860/. Diakses: 21 Desember 2018.

Temaluru, N.A.R., Asnawi., dan Falah. 2016. Pengaruh penerapan unit layanan pengadaan (ULP) terhadap efisiensi dan efektifitas pengadaan barang atau jasa pada pemerintah propinsi Papua. Jurnal Keuda 1(1): 127-151.

Thoyibatun, S. 2012. Faktor-faktor yang berpengaruh terhadap perilaku tidak etis dan kecenderungan akuntansi serta akibatnya terhadap kinerja organisasi. Jurnal Ekonomi Dan Keuangan 16(2): 245260.

Udayani, A.A.K.F. dan M. M. R. Sari. 2017. Pengaruh pengendalian internal dan moralitas individu pada kecenderungan kecurangan akuntansi. E-Jurnal Akuntansi 18(3): 1774-1799.

Ugrin, J. C., M. D. Odom dan R. L. Ott. 2014. Examining the effects of motive and potential detection on the anticipation of consequences for financial statement fraud. Journal of Forensic and Investigative Accounting 6(1): 151-180. 
Vries, H. D., V. Bekkers, dan Tummers. 2015. Innovation in the public sector: A systematic review and future research agenda. Public Administration 94(1): 146166.

Wu, S. P .J., D. W. Straub., dan T. P. Liang. 2015. How Information Technology Governance Mechanisms and Strategic Alignment Influence Organizational Performance: Insights from a Matched
Survey of Business and IT Managers. Management Information Systems Quartely 39(2): 497-518.

Zhang, Q. dan H. Zhao. 2017. An Analytical Overview of Kohlberg's Theory of Moral Development in College Moral Education in Mainland China. Open Journal of Social Sciences, 5: 151-160. 